\title{
Elites and Brexit: Realignment in the House of Lords, 2000-2022
}

\author{
Marc S. Jacob* \\ Ugur Ozdemir $^{\dagger}$ \\ First draft: January 2021 \\ Current version: July 14, 2022
}

\begin{abstract}
There is ample evidence that the 2016 Brexit referendum polarized British society and political elites alike, but the implications for voting alliances in the House of Lords, the UK's upper chamber, are less known. We examine whether new voting alliances have emerged since the referendum and how lasting these alliances are. Analyzing original roll-call data between 2000 and 2022, we find that attendance in the Lords increased and that government defeats have become more frequent since the Conservatives regained the absolute majority in the Commons in 2015. Moreover, the new alliance between Labour and Liberal Democrats remained strong even as the parliamentary agenda was less dominated by Brexit legislation after the UK's withdrawal from the EU. Our results speak to the ongoing debate on whether British politics has undergone a process of realignment and yield implications for the responsiveness of upper chambers to societal change more generally.
\end{abstract}

Keywords-House of Lords, bicameralism, second chambers, realignment, Brexit, United Kingdom

\footnotetext{
*Ph.D. Candidate, Center for Comparative and International Studies, ETH Zurich, Switzerland, majacob@ethz.ch.

${ }^{\dagger}$ Lecturer, School of Social and Political Science, University of Edinburgh, United Kingdom, ugur.ozdemir@ed.ac.uk
} 


\section{Introduction}

Even second chambers that cannot veto bills may exert influence over legislative outcomes. By being able to delay legislation, upper chambers can prevent the government from implementing policies in a timely fashion. This is why also 'weaker' upper chambers' concerns are usually taken into account rather than ignored in bicameral legislative processes (Tsebelis and Money, 1997). The perhaps most impressive demonstration of this mechanism has been the United Kingdom's withdrawal from the European Union (EU) following a national referendum in 2016. Within a short period of time, the British government was tasked with passing various important bills related to the far-reaching decision to leave the EU.

Nonetheless, the need for passing urgent legislation did not discourage the UK's upper house from expressing concerns and voting against the government. Quite the opposite: since the Conservative Party regained full control over the UK government in $2015,{ }^{1}$ the House of Lords has been challenging the government substantially more often than in previous terms. ${ }^{2}$ As Figure 1 indicates, the Conservative government was defeated in about half of the floor votes between 2015 and 2017 and seems to have faced a relatively high level of dissent in subsequent terms. The increasing number of government defeats suggests that it has become more challenging for the government to find majorities in the Lords, a development rarely noticed by the British public.

While existing scholarship has extensively examined the ramifications of the decisive 2016 referendum for British society (e.g., Hobolt, Leeper, and Tilley, 2020; Sobolewska and Ford, 2020), the implications of the UK's withdrawal from the EU for legislative procedures in the UK's upper chamber are less well understood. Studies on voting patterns in the Lords before Brexit suggest that depending on the government party, either the Liberal Democrats (LibDems) or Crossbenchers, two of the primary parliamentary groups in the Lords, have been pivotal in Lords divisions (Russell, 2013, p. 126), suggesting that voting alliances are not stable over time. Highlighting the more volatile voting patterns in the Lords, Parkinson (2007) argues that the Lords is characterized by more deliberative decision making and thereby contributes to scrutinizing the government's actions as well as decisions made in the Commons.

\footnotetext{
${ }^{1}$ The Conservatives formed a coalition with the Liberal Democrats between 2010 and 2015.

${ }^{2}$ Note that the bulk of government defeats concern amendments rather than the outright rejection of entire government bills.
} 


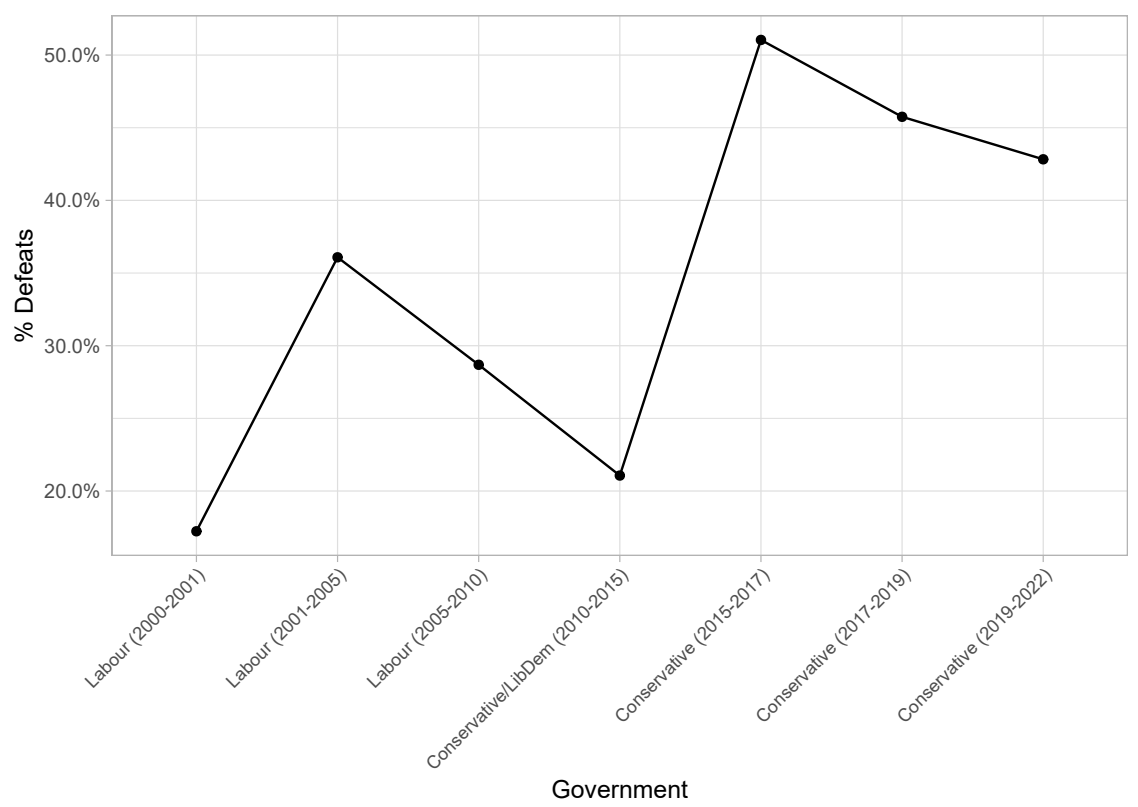

Figure 1: Share of government defeats in divisions in the House of Lords by government.

But how has the Lords responded to the 2016 Brexit referendum outcome, and what voting alliances have emerged from that far-reaching decision? We address this question by drawing on Smith (2019), who finds that in the immediate aftermath of the referendum, Labour and LibDems formed an alliance that opposed a "hard" Brexit and voted against several Conservative government bills that, among others, envisioned a full withdrawal from the European Single Market. We develop two diverging expectations as to whether the Conservative vs Labour and LibDems divide in the Lords has persisted into the post-withdrawal period, in which Westminster turned to more day-to-day business and other salient issues such as the Covid-19 pandemic.

For one, returning to "ordinary" parliamentary business might have facilitated deliberative decision-making in the Lords, whereby the polarization between Conservative peers on the one hand and Labour and LibDem peers on the other might have decreased. Alternatively, the remarkably salient and polarizing Brexit issue might have induced a realignment in the UK's upper chamber, a process in which voting behaviour is increasingly structured along a single dimension, and alternating voting alliances occur less often.

To examine whether voting in the Lords has returned to pre-Brexit patterns or the Lords has undergone a process of realignment, we leverage an original dataset documenting all votes cast in about 2,200 divisions from 2000 to 2022. To study party cohesion and voting alliances in the 
Lords, we employ an Optimal Classification (OC) approach (Armstrong et al., 2014; Poole, 2005), which estimates peers' ideal points based on their voting records.

We find that the distinct voting patterns of the main party groups (i.e., Conservative, Labour, and LibDems) transformed into a bipolar structure between a temporarily more fragmented Conservative parliamentary group and a strikingly united coalition of LibDem and Labour peers. Moreover, peers have attended divisions more frequently over time and, under the most recent Conservative government (2019-), within-party cohesion is strikingly strong while vote margins in divisions a usually narrow. These findings provide evidence for a realignment of voting alliances in the Lords, where formerly existing multidimensional voting patterns have been replaced by a single issue dividing the Lords, the UK's relationship with the European Union (EU).

Our paper aims to make three contributions. First, we extend existing analyses of voting in the UK's upper chamber (Dewan and Spirling, 2011; Norton, 2003; Russell, 2013) to a decisive period in more recent British history, the post-referendum years. Analyzing voting alliances in this period offers an opportunity to evaluate whether voting patterns identified before Brexit in previous scholarship have remained stable even during various polarizing divisions following the 2016 referendum.

Second, our study speaks to the ongoing debate on whether or not British politics and society have undergone an electoral realignment in recent years (Cutts et al., 2020; Fieldhouse et al., 2021; Hobolt, Leeper, and Tilley, 2020). The finding of a new bipolar voting pattern in the Lords suggests that elites have reshuffled their voting alliances since the referendum despite the absence of reelection pressure. Even though most peers have been appointed way before Westminster discussed and voted on Brexit bills, voting alliances in the Lords appear to reflect divides in the broader British electorate.

Lastly, our study contributes to the literature on bicameralism and voting behaviour in upper chambers (Borthwick, 2001; Coakley, 2014; Cutrone and McCarty, 2006; Diermeier and Myerson, 1999; Druckman and Thies, 2002; Fisk, 2011; Lijphart, 2012; Riker, 1992; Russell, 2001, 2012; Tsebelis and Money, 1997). Given the lifetime and more representative appointments of peers, the case of Brexit allows evaluating how highly salient and polarizing events such as a referendum affect decision-making in upper chambers despite a membership composition different from the lower chamber and comparatively weak sanctioning mechanisms to contain defections from party 
lines.

\section{Brexit and voting in the House of Lords}

\section{Brexit as a turning point in British politics and society}

In a nationwide referendum on 23 June 2016, after months of polarized campaigning, millions of British citizens voted either against or in favour of the UK's withdrawal from the European Union. The divide between the Leave and Remain camps has been the primary analytical lens in understanding British politics since then (Surridge, 2021). Hobolt, Leeper, and Tilley (2020) show that the polarization triggered by the referendum continues to divide British society even as EU membership and EU integration have not always been the most salient issue since 2016.

Sobolewska and Ford (2020, p. 12) argue that the referendum itself was not the cause of this divide but instead provided a 'moment of awakening' for identity conflicts that had been growing in previous decades. They claim that the growing differences in values and priorities crystallized into a concrete conflict and created two tribes of antagonists (Sobolewska and Ford, 2020, p. 12). And yet, while providing a broader historical perspective on Brexit, in this line of research, the

referendum is still considered a historical turning point that contributed to newly emerging partisan identities.

In a similar vein, analyzing electoral behaviour in the 2019 general election, Cutts et al. (2020) find that while the Conservatives have increased their vote share in constituencies that were formerly Labour strongholds, these changing support patterns can be seen as a long-term process in which Labour has lost substantial parts of its former voter base. These class realignments are strongly related to Britons' stance on the Brexit issue and "appear to have implanted a new, potent cultural divide at the heart of British politics" (Cutts et al., 2020, p. 20).

Simultaneously to these changes at the mass level before and after Brexit, the UK's party system and British politics more generally underwent considerable transformations as well. Denver and Johns (2022) note that the relative strength of the LibDems in the pre-Brexit era again transformed into a duopoly of the British party system following the 2017 election. Recent polls corroborate the claim that British politics is returning to two-party politics (Surridge, 2021). This 
development can, among others, be attributed to the UK's electoral system for the Commons, which poses high bars for smaller parties to challenge the two principal parties.

However, the Brexit issue also directly affected debates and procedures in Westminster. Baldini, Bressanelli, and Massetti (2018, p. 543) observe that the government has sought to bypass parliament on several occasions in the aftermath of the Brexit referendum, most notably when seeking to officially withdraw from the European Union (i.e., to trigger Article 50 of the Treaty on European Union). At the same time, these attempts were met with some resistance from parliament, including the House of Lords.

Most visible to the British public were controversial debates and votes in the House of Commons following the Brexit referendum. The May government had to face the most severe defeat in the Commons in recent Westminster history when a high share of Conservative MPs defected from the party line in the so-called 'Meaningful Votes' on the Withdrawal agreement between the government and the EU between January and March 2019. Aidt, Grey, and Savu (2021) find that Conservative MPs who voted against the government were driven mainly by political preferences (i.e., they were in favour of Brexit in the referendum campaign), but also constituency preferences and career concerns played a role.

MP's different positions on the Brexit issue also shaped participation and rhetoric in debates in the Commons. Umit and Auel (2020) find that MPs who are opposed to leaving the EU after the Brexit referendum speak up comparatively often in the Commons and engage in negative language. By contrast, MPs whose preferences deviate from their party participate less often in parliament and use less negative language.

Taken together, previous research indicates that the Brexit issue reshuffled citizens' political preferences and voting behaviour, as well as politics and MP's behaviour in Westminster. This paper contributes to our knowledge about the consequences of Brexit on British politics and society by studying how voting patterns in the House of Lords have changed before and after the Brexit vote. Before formulating expectations about these transformations, we first review existing scholarship on voting in the House of Lords. 


\section{Previous research on voting in the House of Lords}

While the UK House of Lords has much in common with other upper houses in parliamentary systems, the chamber's most unique feature relates to its composition of members. In many second chambers, members represent territorial units or are elected like their counterparts in the first chamber but with a different electoral system. Members of the Lords, by contrast, gain their seats through appointment. Most of them are proposed by the Prime Minister and formally appointed by the monarch, yet a few members, the hereditary peers, nominate the successors of deceased peers among themselves (Borthwick, 2001, p. 19).

Another particularity of the UK's second chamber is its members' lifetime appointment. ${ }^{3}$ In contrast to most lower chambers in parliamentary systems, which are usually characterized by strong party discipline, the Lords is a relatively discipline-free environment. However, although neither the majority nor the opposition party in the House of Commons possesses powerful sanctions that would encourage members of the Lords to follow the frontbench in its voting recommendations, scholars have pointed to established norms among the peers (Norton, 2003; Russell, 2013). This is why cohesion within the Conservative, Labour, and LibDems parliamentary groups is relatively strong despite the lack of sanctioning mechanisms (Russell, 2013, pp. 113-114).

A few studies have already examined voting behaviour in the Lords before Brexit, providing valuable insights into the Lords' leverage in shaping policy in Westminster. Dewan and Spirling (2011), analyzing roll-call data from 2001 to 2005, find that despite the absence of electoral incentives, peers' voting behaviour can be sorted along a single pro- versus anti-government dimension, thereby mirroring voting patterns in the Commons.

Russell (2013) provides the most comprehensive analysis of voting in the Lords between 1999 and 2013 to date. Focusing on the determinants of legislative defeats of the government in the Lords ("Lord defeats"), Russell (2013, p. 162) reports that such defeats occur considerably more frequently than in the Commons and more often in votes on significant policies. Nonetheless, the Lords most often propose amendments to government bills rather than rejecting them in their entirety.

As for voting alliances in the Lords, Russell (2013, p. 126) finds that in the post-1999 Lords, "various groups of peers now have the potential to be 'pivotal voters' in the chamber." During

\footnotetext{
${ }^{3}$ An exception to the rule are the Bishops, who usually leave the Lords upon retirement (Russell, 2013, p. 70).
} 
the Labour government, the LibDems were usually pivotal whether or not the government was defeated. During the Conservative/LibDem government, the number of Lord defeats did not decline but remained at a similar level. Under this government, the Crossbenchers took over to be the pivotal voter in the Lords, suggesting that this parliamentary group has become more important in voting in the Lords (Russell, 2013, p. 126).

Overall, the presented evidence suggests that voting in Lords depends on which parties form the government and, closely intertwined, that voting alliances in the second chamber can take different forms. In this paper, we seek to study whether this pattern has carried over to the post-Brexit era and, if so, what these shifts in voting behaviour look like.

\section{Expectations: realignment or return to pre-Brexit patterns?}

This section develops expectations of how voting behaviour might have changed before and after the Brexit issue became salient in the wake of the 2016 referendum. Studies have shown that government defeats in the Commons have been increasing in the aftermath of the Brexit referendum, mainly because Conservative MPs tended to defect more often from the party line in divisions related to the UK's departure from the EU (Kirkland and Slapin, 2018). As for the Lords, Smith (2019) examines the behaviour of peer groups in the Lords in the aftermath of the referendum. In most instances, Conservative peers did not defect from the party line, partially because already prior to the 2017 elections, defecting peers were removed from Committee positions and/or not nominated for such posts if their tenure expired (Smith, 2019, p. 96).

By contrast, LibDems and most Labour peers opposed a "hard" stance on Brexit and hence voted against government bills proposing such legislation. Crossbenchers differ substantially in their views of Brexit, where some members of this group allied with Labour and LibDems to challenge government bills on the future relationship between the EU and the UK, and others joined the Conservatives to back the government (Smith, 2019, p. 99).

Based on these insights, we expect the Lords to be divided between Conservative and several Crossbenchers on the one hand and LibDems, Labour, and more europhile Crossbenchers on the other in the aftermath of Brexit. Between 2015 and 2020, when the final withdrawal agreement was reached, the legislative agenda in Westminster was dominated by the UK's future relationship 
with the EU, whereby this bipolarity between eurosceptic and europhile peers is likely to have shaped voting patterns in the Lords.

However, has this bipolar pattern carried over to the post-withdrawal period? On the one hand, the Conservative government under Boris Johnson has maintained a rather eurosceptic view and faces strong opposition to legislation in the Commons. Moreover, Brexit has dominated the agenda in Westminster for several years, and it could be the case that the Conservative vs Labour/LibDem division continues to guide MP's and Lords' voting behaviour even though parliament has turned to discuss bills unrelated to Brexit more often. If this scenario were true, voting in the Lord would have undergone a process of realignment, where changing voting alliances between peer groups would have been replaced by a strong bipolar alliance structure in divisions in the Lords.

On the other hand, the UK's withdrawal from the EU and the regained cohesion among the Conservatives in the Commons and, to some extent, in the Lords might have facilitated the reemergence of pre-Brexit voting patterns. In this scenario, the three main parties in the Lords (Conservative, Labour, LibDems) exhibit distinct voting patterns, whereby the bipolar structure transforms into a tripolar pattern, with the Crossbenchers heavily differing in their voting behaviour.

To summarize, while we expect a strong bipolar voting pattern between europhile and eurosceptic groups in the Lords up until the UK's withdrawal from the EU, the nature of voting behaviour since then is somewhat unclear. Hence, our study seeks to examine whether the post-withdrawal period is characterized by an ideological realignment between europhile and eurosceptic party groups in the Lords or returned to its pre-Brexit multipolar voting structure.

\section{Attendance, cohesion, and voting alliances in the Lords, 2000-}

\section{2}

\section{Data and method}

Our analysis of voting in the Lords relies on an original dataset of all roll-call votes between 2000 and 2022, totalling almost 2700 divisions. In the UK Westminster system, legislators' votes in divisions are well documented, both in the Commons and Lords. Hence, our data documents whether peers participating in divisions voted for (content) or against (not content) a bill. 
Besides evaluating descriptive evidence, we analyze the data by employing Optimal Classification (OC) models (Armstrong et al., 2014; Poole, 2000, 2005; Rosenthal and Voeten, 2004). OC is a non-parametric ideal point estimation method that assumes that legislators' votes result from their individual utility functions. Put differently, legislators' votes cast in divisions allow us to map voting behaviour in a voting space. In comparison to parametric ideal point estimation approaches such as W-NOMINATE, OC only relies on the assumption that the latent voting space is Euclidean, legislators cast their votes sincerely, keep the same policy preferences over time, and individuals' utility functions are single-peaked and symmetric (Armstrong et al., 2014, p. 249).

A few studies have raised concerns about whether these assumptions are met in the context of parliamentary systems (Bräuninger, Müller, and Stecker, 2016; Spirling and McLean, 2007). Crucially, legislators may not only vote based on their policy preferences but on strategic grounds. It has been argued that sanctioning mechanisms, aiming at strengthening cohesion within parliamentary groups, prevent legislators from voting in line with their ideological preferences (Spirling and McLean, 2007, p. 88). Consequently, estimating legislators' ideal points based on votes cast may lead to inaccurate results when strong exogenous factors, such as punishment for defecting from the party line, are present in a parliament.

While these exogenous factors are undoubtedly present in the Commons, peers have relatively little reason to fear sanctions when voting against the party line. Thus, although weaker sanctioning mechanisms such as removing peers from committees (Smith, 2019) and social desirability may still conceal peers' ideological preferences, peers could, in principle, vote as they wish while not needing to fear severe punishment. Still, we interpret our results only with respect to observed voting behaviour and alliances, without drawing inferences about peers' individual preferences.

In line with previous research, we only include divisions in which more than 2.5 per cent of the peers cast a vote for the minority position (Rosenthal and Voeten, 2004, p. 623). Almost unanimous divisions appear only three times in the entire voting period. As for the number of peers included in the analysis, we estimate the ideal points of members who have participated in at least ten per cent of all divisions. Since the Lords is not a full-time chamber and a portion of peers does not regularly participate in divisions, we can only reliably determine the ideal points for members who have voted in a sufficient number of divisions. ${ }^{4}$ While we cannot investigate the

\footnotetext{
${ }^{4}$ Because the bishops usually rotate in their attendance in debates and divisions in the Lords, this group of peers is
} 


\begin{tabular}{lcccccc}
\hline Party & $\begin{array}{c}\text { Labour } \\
\text { Government } \\
(2001-2005)\end{array}$ & $\begin{array}{c}\text { Labour } \\
\text { Government } \\
(2005-2010)\end{array}$ & $\begin{array}{c}\text { Conservative/ } \\
\text { LibDem } \\
\text { Government } \\
(2010-2015)\end{array}$ & $\begin{array}{c}\text { Conservative } \\
\text { Government } \\
(2015-2017)\end{array}$ & $\begin{array}{c}\text { Conservative } \\
\text { Government }\end{array}$ & $\begin{array}{c}\text { Conservative } \\
\text { Government } \\
(2017-2019)\end{array}$ \\
\hline Conservative & 175 & 191 & 222 & 252 & 248 & 266 \\
Crossbench & 64 & 88 & 117 & 113 & 132 & 128 \\
Labour & 194 & 221 & 223 & 198 & 183 & 175 \\
Liberal Democrat & 67 & 77 & 100 & 105 & 94 & 86 \\
Non-affiliated & 1 & 2 & 8 & 15 & 19 & 37 \\
Other party & 2 & 4 & 11 & 9 & 10 & 11 \\
\hline
\end{tabular}

Table 1: Effective number of peers and divisions considered in the analysis.

\begin{tabular}{|c|c|c|c|c|c|c|}
\hline & $\begin{array}{c}\text { Labour } \\
\text { Government } \\
(2001-2005)\end{array}$ & $\begin{array}{c}\text { Labour } \\
\text { Government } \\
(2005-2010)\end{array}$ & $\begin{array}{l}\text { Conservative/ } \\
\text { LibDem } \\
\text { Government } \\
(2010-2015)\end{array}$ & $\begin{array}{l}\text { Conservative } \\
\text { Government } \\
(2015-2017)\end{array}$ & $\begin{array}{l}\text { Conservative } \\
\text { Government } \\
(2017-2019)\end{array}$ & $\begin{array}{l}\text { Conservative } \\
\text { Government } \\
(2019-2022)\end{array}$ \\
\hline$N$ Peers & 504 & 584 & 685 & 693 & 691 & 709 \\
\hline$N$ Divisions & 544 & 607 & 403 & 191 & 138 & 310 \\
\hline $\begin{array}{l}\text { Correctly } \\
\text { Predicted } \\
\text { Contents }\end{array}$ & $\begin{array}{c}52979 \text { of } 53733 \\
(98.6 \%)\end{array}$ & $\begin{array}{c}61773 \text { of } 63510 \\
(97.3 \%)\end{array}$ & $\begin{array}{c}65076 \text { of } 67097 \\
(97 \%)\end{array}$ & $\begin{array}{c}31569 \text { of } 32051 \\
(98.5 \%)\end{array}$ & $\begin{array}{c}23988 \text { of } 24321 \\
(98.6 \%)\end{array}$ & $\begin{array}{c}62136 \text { of } 64130 \\
(96.9 \%)\end{array}$ \\
\hline $\begin{array}{l}\text { Correctly } \\
\text { Predicted } \\
\text { Not Contents }\end{array}$ & $\begin{array}{c}58942 \text { of } 59860 \\
(98.5 \%)\end{array}$ & $\begin{array}{c}76694 \text { of } 78124 \\
(98.2 \%)\end{array}$ & $\begin{array}{c}77053 \text { of } 78747 \\
(97.8 \%)\end{array}$ & $\begin{array}{c}35458 \text { of } 35804 \\
(99 \%)\end{array}$ & $\begin{array}{c}24514 \text { of } 24837 \\
(98.7 \%)\end{array}$ & $\begin{array}{c}62807 \text { of } 64388 \\
(97.5 \%)\end{array}$ \\
\hline
\end{tabular}

Table 2: OC model diagnostics by government.

policy preferences of peers who only occasionally cast votes in the Lords, we hold that the most active peers are also those who have the most significant influence in divisions in the Lords. After all, it matters most how many votes are cast either in favour or against a bill. We implement OC models for all government periods, i.e., two Labour governments (2001-2005, 2005-2010), one Conservative/LibDem government (2010-2015), and three Conservative governments (2015-2017, 2017-2019, 2019-2022). Table 1 provides the effective number of Lords and divisions included in the analysis for each term. As Table 2 shows, at least 97 per cent of 'Contents' and 95.5 per cent of 'Not Contents' were correctly classified with an OC model with two dimensions, indicating that most individual votes cast in the Lords are correctly predicted.

removed from the analysis. 


\section{Attendance}

Before reporting the results obtained from the ideal point estimation, we first evaluate attendance in divisions over time. Figure 2 shows the mean share of divisions in which peers cast a vote by government period and parliamentary group. Except for Labour peers, all groups of peers have voted more regularly in divisions during more recent governments, where the most significant increase can be observed for Conservative and LibDem peers. While Labour peers attended the most often during the Labour governments until 2010, Conservatives and LibDems appear to be most active in divisions in subsequent terms.

However, also Crossbenchers, peers affiliated with another party or none ('Other') and, to some degree, Bishops have participated in votes more frequently over time. Overall, the development of votes cast over time suggests that peers have become more active in parliamentary business. Moreover, these trajectories may also indicate that peers assign voting greater importance than in previous terms, supporting the claim that members of the Lords have come to define their role more as an active legislator rather than a part-time member who only occasionally turns out to vote in divisions, for instance, when a division is whipped.

\section{Cohesion}

How has the cohesion in the Lords and within party groups developed before and after Brexit? Interestingly, as Figure 3(a) shows, voting cohesion has not become lower in the Lords in the aftermath of the 2016 referendum. On the contrary, cohesion grew during the 2015-2017 and 2017-2019 governments from the lowest level recorded in the 2010-2015 Conservative/LibDem government. During the most recent Conservative government (2019-), however, cohesion declined once again. Overall, the post-Brexit period seems not to have caused less agreement in divisions over time. Instead, cohesion in the Lords has always been at relatively low levels, a finding that is consistent with evidence from the pre-Brexit period in which the margins in divisions were often narrow (Russell, 2013, pp. 116-124).

Figure 3(b) displays the level of cohesion among the main party groups in the Lords. Apart from a slightly weaker cohesion within the LibDem group during the 2010-2015 government, all three parties exhibited remarkable cohesion in the pre-Brexit period. Between 2017 and 2019, 


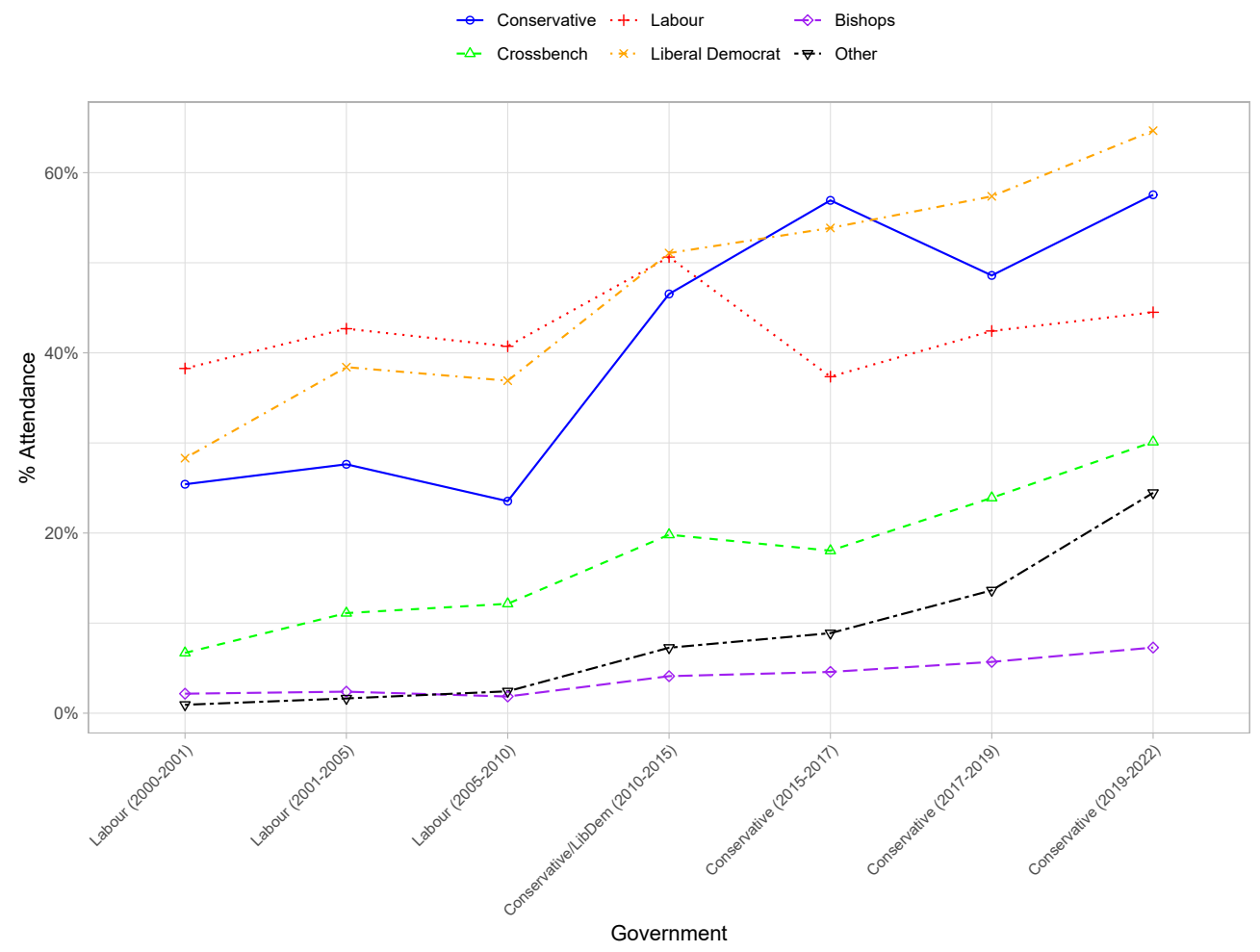

Figure 2: Mean percentage of attendance in House of Lords divisions by parliamentary group. Members are considered in the analysis when they cast a least one vote in a given government period. In some instances, newly appointed peers who were not eligible to vote in previous divisions during a government enter the analysis. Given the large membership and the few yearly appointed peers to the Lords, the mean percentage scores reported will be marginally upward biased.

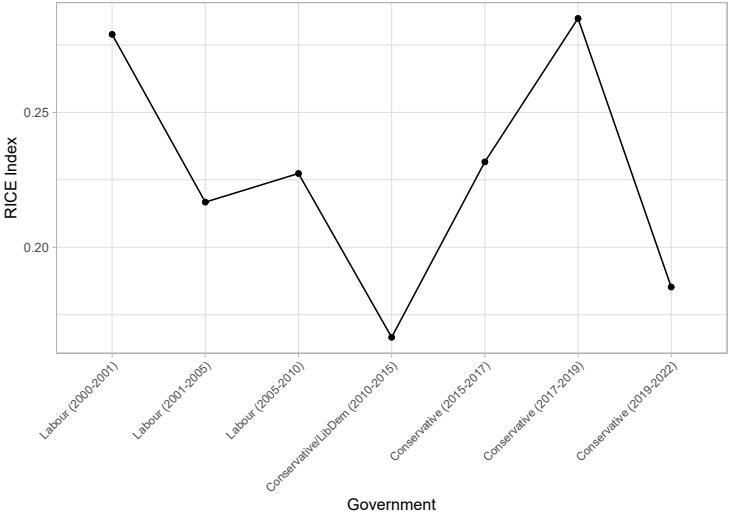

(a) All members

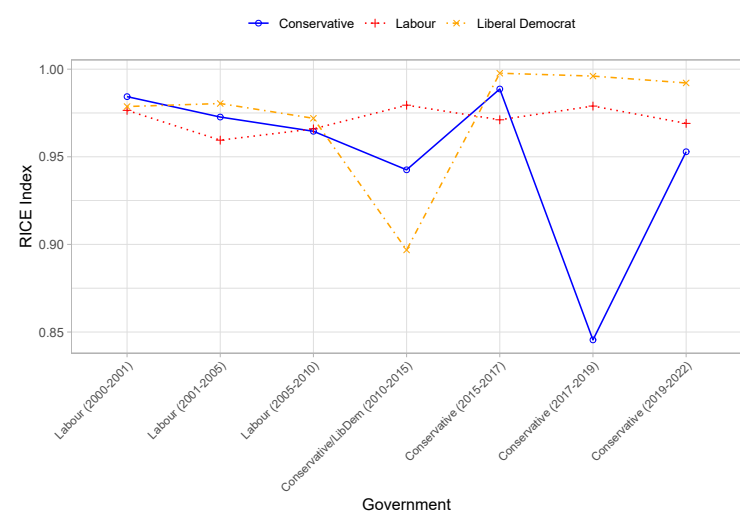

(b) By parliamentary group (Crossbenchers and other members omitted)

Figure 3: Rice index by government period. The Rice index is computed as follows: RICE = $\frac{\mid \text { Content-NotContent } \mid}{\text { Content }+ \text { NotContent }}$, where higher values indicate higher and lower values lower voting cohesion. 


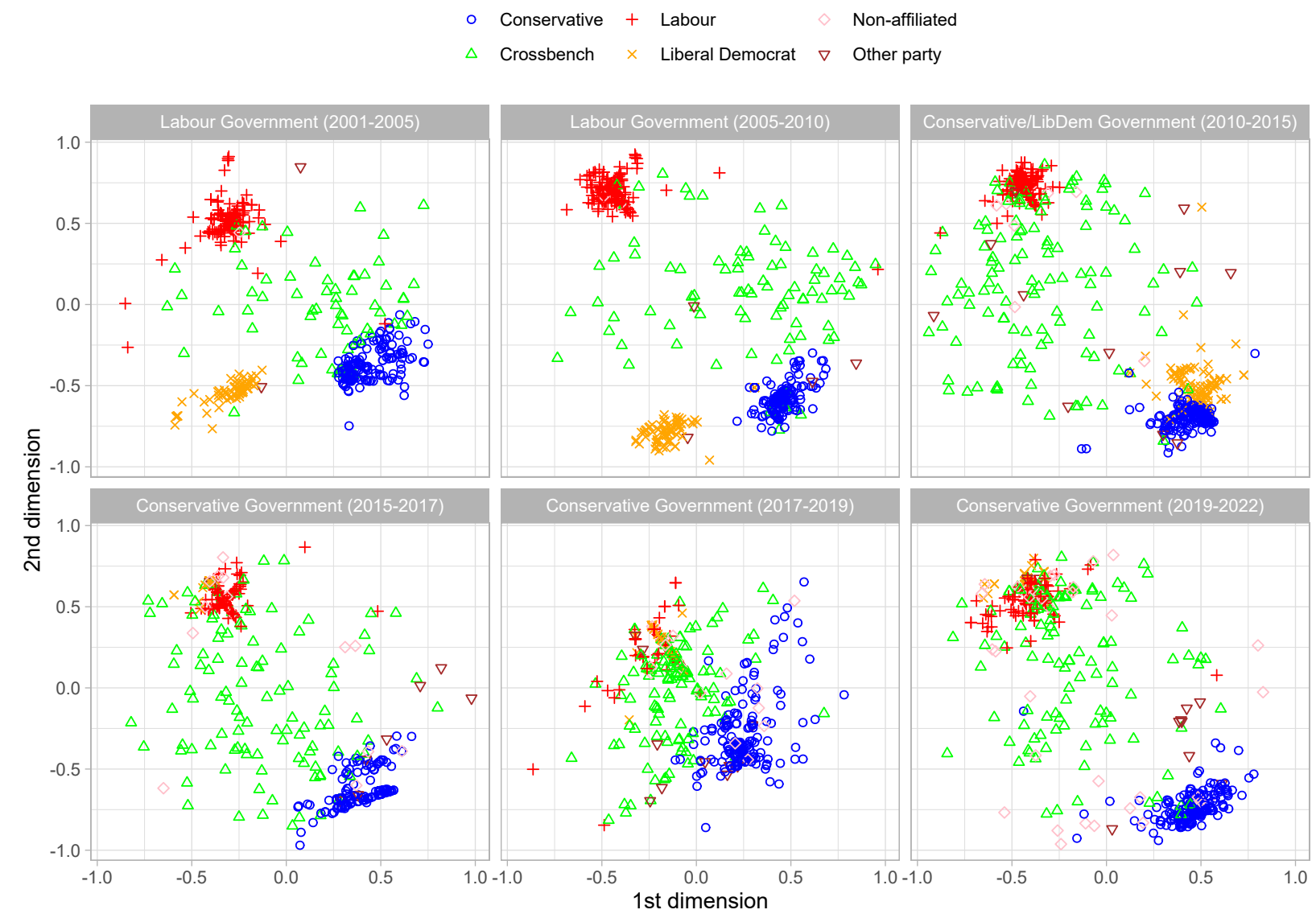

Figure 4: Optimal Classification ideal point estimates of House of Lords members, 2000-2022. Estimates were rotated with a rotation matrix of $\theta=45$. See Online Appendix A for scree plot and bill cutting lines.

voting in the Conservative group appeared to be more heterogeneous than previous terms. By contrast, Labour and particularly the LibDems vote as a bloc in almost all divisions. In the most recent term (2019-2022), the Conservatives became more coherent in their voting behaviour, suggesting an increasing unity in policy-making in the post-withdrawal period.

\section{Voting alliances}

Having found that peers tend to participate in divisions more often in recent years and usually vote as party blocs also after Brexit, we now evaluate the results of the ideal point estimation. Figure 4 depicts peers' ideal point estimates by government based on votes cast in the Lords. Figure 5 plots the distribution of ideal point estimates separately for the first and second dimensions.

During both Labour governments (2001-2005, 2005-2010), the Lords was characterized by a 
tripolar voting space. In both periods, Labour, Conservatives, and LibDems exhibited distinct voting patterns, where the LibDems were slightly closer to the Conservatives than to Labour. Under the second Labour government, the gap between opposition and government parties became more significant, with the Crossbenchers taking various ideological positions between government and opposition parties. This pattern changed moderately as Conservatives and LibDems formed a government in 2010. Conservatives and LibDems moved closer to each other in the voting behaviour, but the two parties did not entirely form a single voting bloc in the Lords.

A more dramatic shift emerged after the 2015 election. Even though Conservatives and LibDems formed a government for five years, LibDem peers no longer occupied a unique position in the voting space in the Lords but fully joined the Labour bloc in divisions. This pattern can also be observed in subsequent terms. Even though voting cohesion was relatively weak in the Conservative group, Labour and LibDems retained their voting coalition.

Strikingly, even though most Brexit legislation had already passed Westminster by 2019, Labour and LibDems did not assume distinct voting patterns during the Johnson government (2019-) but still voted anonymously as a bloc against the governing Conservatives. During all Conservative governments from 2015 onwards, most Crossbenchers exhibit ideal points on the first dimension similar to Labour and LibDems. On the second dimension, however, Crossbechers vary considerably with respect to their voting behaviour, where most of them appear to assume a moderate position between government and opposition parties.

These findings provide evidence for a distinct new voting pattern in the Lords since the 2015 election. Even as most Brexit bills finally passed parliament, Labour and LibDems continued to form a voting alliance while the Conservatives regained their solid cohesion that was unusually weak during the 2017-2019 government.

\section{Conclusions: evidence for realignment and implications for bi-}

\section{cameralism}

'Weak' second chambers that do not possess veto power can leverage their right to delay legislation most effectively when the pressure to pass bills is high. This was precisely the case when the UK 


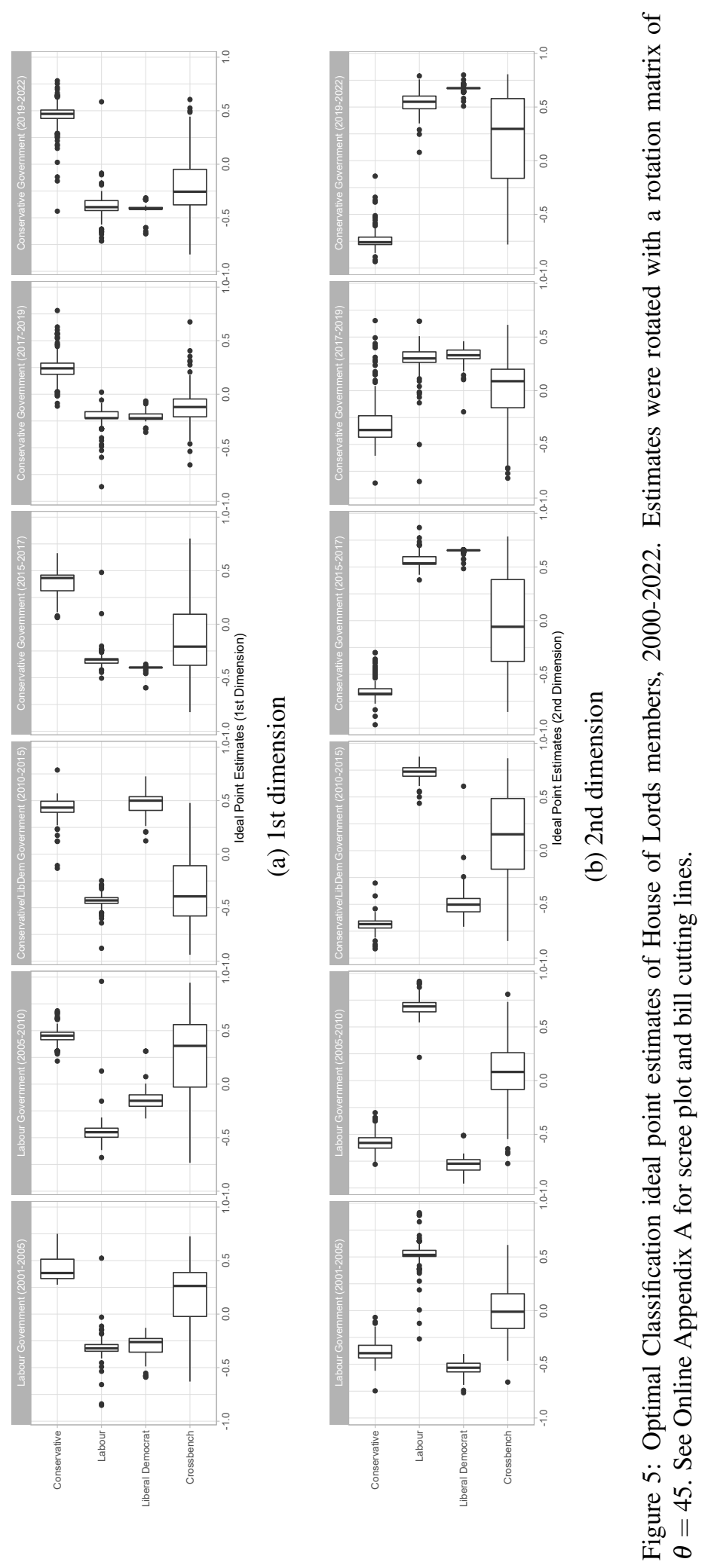


government was navigating through the ramifications of the 2016 Brexit referendum outcome: in a relatively short period of time, Westminster had to pass various important bills that were met with strong opposition both from the Commons and the Lords. To better understand the growing number of government defeats in the UK's upper chamber, we examine how voting behaviour and alliances in the Lords have changed before and after the Brexit referendum. Drawing on Smith (2019), we expect the multipolar House of Lords to collapse into bipolar voting blocs, where the Conservatives oppose a coherent opposition consisting of Labour and LibDems. This paper aims to study whether this bipolar structure returned to pre-Brexit voting patterns after the most controversial Brexit issues had been settled in Westminster.

An ideal point analysis of two decades of voting in the Lords suggests that Labour and LibDem peers no longer represent two distinct voting blocs but form a single voting alliance opposing the Conservative government. Although Brexit no longer dominates policy-making in parliament, this pattern has carried over to the current Conservative government. Hence, UK's withdrawal from the EU seems to have substantially restructured voting alliances in the Lords. While voting in the Lords was dominated by distinct voting behaviours of the three principal party groups in the preBrexit period, voting has become uni-dimensional after Brexit, where Labour peers and Liberal Democrats vote almost always unanimously against the Conservative government.

These trends have been accompanied by peers' more frequent attendance in divisions. As of the most recent Conservative government (2019-), the highest share of peers participated in voting decisions while the cohesion within party groups is remarkably strong. And yet, the new alliance between Labour and LibDems explains why the Conservative government experienced a comparatively high number of defeats in the upper chamber not only in the immediate aftermath of the 2016 Brexit referendum but even after the UK officially withdrew from the EU.

These developments suggest that voting behaviour in the Lords has undergone a realignment, a process in which distinct party preferences have been transformed into a bipolar voting pattern that can mainly be attributed to conflicts over the UK's exit from the EU. We conclude that even in the UK's second chamber, whose members were mostly appointed before the 2016 referendum and did not have to be concerned about reelection, Brexit reshuffled the UK elites' voting behaviour substantially, even after Westminster returned to "ordinary" business after the UK's withdrawal from the EU. 
These findings speak to the ongoing debate on whether British society in general has experienced a realignment in the wake of the 2016 referendum. While it remains to be seen as to whether the bipolar voting alliances in the Lords continue to shape the legislative process also during future governments, it appears that the realignment at the citizen level (Cutts et al., 2020; Fieldhouse et al., 2021) also concerns Britain's elites in the upper chamber. Even without being directly held accountable by voters and parties for their voting behaviour, peers seem to follow developments in broader politics and society and behave accordingly.

These insights have implications for bicameralism more generally. Albeit the absence of direct elections and reelection pressure, members of upper chambers seem to be responsive to shifts in political alliances within and between political parties as well as segments in the electorate. The case of the Lords does not provide evidence for scholarly and public concerns that unelected elites tend to be more ignorant about public opinion or transformations in the party system. However, one critical scope condition of this finding is the presence of strong parties that, at least partially, propose which citizens be appointed to the upper chamber. The UK's appointment system to the upper chamber induces loyalties between most of the peers and party groups (cf. Crewe, 2005; Russell, 2014), ensuring voting cohesion and congruence to political parties' policy platforms.

While our study finds that the UK's second chamber provides evidence for a realignment in voting patterns since the 2016 Brexit referendum, we still know little about the dynamics between Westminster's two chambers. Do the margins of division outcomes in the Commons influence peers' voting behaviour on the same bill? Another promising avenue of research may be to examine changes of, or continuities in, voting patterns of peers who previously served as members of the Commons. The analysis of whether the same legislator's behaviour changes in different institutional environments may not only provide insights into the logic of parliamentary behaviour in the Westminster system but also into the influence of institutional environments on individual legislators' behaviour in bicameral systems in general.

\section{References}

Aidt, Toke, Felix Grey, and Alexandru Savu (2021). "The Meaningful Votes: Voting on Brexit in the British House of Commons." In: Public Choice 186.3-4, pp. 587-617. 
Armstrong, David A. et al. (2014). Analyzing spatial models of choice and judgment with R. Hoboken: Taylor and Francis.

Baldini, Gianfranco, Edoardo Bressanelli, and Emanuele Massetti (2018). "Who is in Control? Brexit and the Westminster Model.” In: The Political Quarterly 89.4, pp. 537-544.

Borthwick, R. L. (2001). “Methods of Composition of Second Chambers.” In: Journal of Legislative Studies 7.1, pp. 19-26.

Bräuninger, Thomas, Jochen Müller, and Christian Stecker (2016). "Modeling Preferences Using Roll Call Votes in Parliamentary Systems.” In: Political Analysis 24.2, pp. 189-210.

Coakley, John (2014). “The Strange Revival of Bicameralism.” In: The Journal of Legislative Studies 20.4, pp. 542-572.

Crewe, Emma (2005). Lords of parliament: Manners, rituals and politics. Manchester: Manchester University Press.

Cutrone, Michael and Nolan McCarty (2006). "Does bicameralism matter?” In: The Oxford handbook of political economy, pp. 180-195.

Cutts, David et al. (2020). "Brexit, the 2019 General Election and the Realignment of British Politics.” In: The Political Quarterly 91.1, pp. 7-23.

Denver, David and Robert Johns (2022). “The Changing British Party System.” In: Elections and Voters in Britain. Palgrave Macmillan, Cham, pp. 61-96.

Dewan, Torun and Arthur Spirling (2011). "Strategic Opposition and Government Cohesion in Westminster Democracies.” In: American Political Science Review 105.2, pp. 337-358.

Diermeier, Daniel and Roger B. Myerson (1999). "Bicameralism and Its Consequences for the Internal Organization of Legislatures.” In: American Economic Review 89.5, pp. 1182-1196.

Druckman, James N. and Michael F. Thies (2002). "The Importance of Concurrence: The Impact of Bicameralism on Government Formation and Duration.” In: American Journal of Political Science 46.4, p. 760.

Fieldhouse, Edward A. et al. (2021). "Volatility, Realignment and Electoral Shocks: Brexit and the UK General Election of 2019.” In: SSRN Electronic Journal.

Fisk, David (2011). "Superfluous or Mischievous: Evaluating the Determinants of Government Defeats in Second Chambers.” In: Legislative Studies Quarterly 36.2, pp. 231-253. 
Hobolt, Sara B., Thomas J. Leeper, and James Tilley (2020). "Divided by the Vote: Affective Polarization in the Wake of the Brexit Referendum.” In: British Journal of Political Science, pp. 1-18.

Kirkland, Justin H. and Jonathan B. Slapin (2018). Roll Call Rebels: Strategic Dissent in the United States and United Kingdom. Cambridge University Press.

Lijphart, Arend (2012). Patterns of democracy: Government forms and performance in thirty-six countries. 2nd ed. New Haven: Yale University Press.

Norton, Philip (2003). "Part 1: Cohesion.” In: Journal of Legislative Studies 9.4, pp. 57-72.

Parkinson, John (2007). “The House of Lords: A Deliberative Democratic Defence.” In: The Political Quarterly 78.3, pp. 374-381.

Poole, Keith T. (2000). “Nonparametric Unfolding of Binary Choice Data.” In: Political Analysis 8.3, pp. 211-237.

- (2005). Spatial models of parliamentary voting. Analytical methods for social research. Cambridge: Cambridge University Press.

Riker, William H. (1992). “The Justification of Bicameralism.” In: International Political Science Review 13.1, pp. 101-116.

Rosenthal, Howard and Erik Voeten (2004). "Analyzing Roll Calls with Perfect Spatial Voting: France 1946-1958.” In: American journal of political science 48.3, pp. 620-632.

Russell, Meg (2001). "What are Second Chambers for?” In: Parliamentary Affairs 54.3, pp. 442458.

- (2012). "Elected Second Chambers and Their Powers: An International Survey.' In: The Political Quarterly 83.1, pp. 117-129.

- (2013). The Contemporary House of Lords: Westminster Bicameralism Revived. First Edition. Oxford: Oxford University Press.

- (2014). "Parliamentary party cohesion: Some explanations from psychology." In: Party Politics 20.5, pp. 712-723.

Smith, Julie (2019). "Fighting to 'Take Back Control': The House of Lords and Brexit." In: Brexit and Democracy. Palgrave Macmillan, Cham, pp. 81-103.

Sobolewska, Maria and Robert Ford (2020). Brexitland: Identity, Diversity and the Reshaping of British Politics. Cambridge University Press. 
Spirling, Arthur and Iain McLean (2007). "UK OC OK? Interpreting Optimal Classification Scores for the U.K. House of Commons.” In: Political Analysis 15.1, pp. 85-96.

Surridge, Paula (2021). “Post-Brexit British Politics: A Reunited Kingdom?” In: Political Insight 12.1, pp. $8-11$.

Tsebelis, George and Jeannette Money (1997). Bicameralism. Cambridge University Press.

Umit, Resul and Katrin Auel (2020). "Divergent preferences and legislative speeches on Brexit." In: Journal of Elections, Public Opinion \& Parties 30.2, pp. 202-220. 


\section{Online Appendix to "Elites and Brexit: Realignment in the House of Lords, 2000-2022"}

July 14, 2022

\section{A Optimal classification diagnostics}
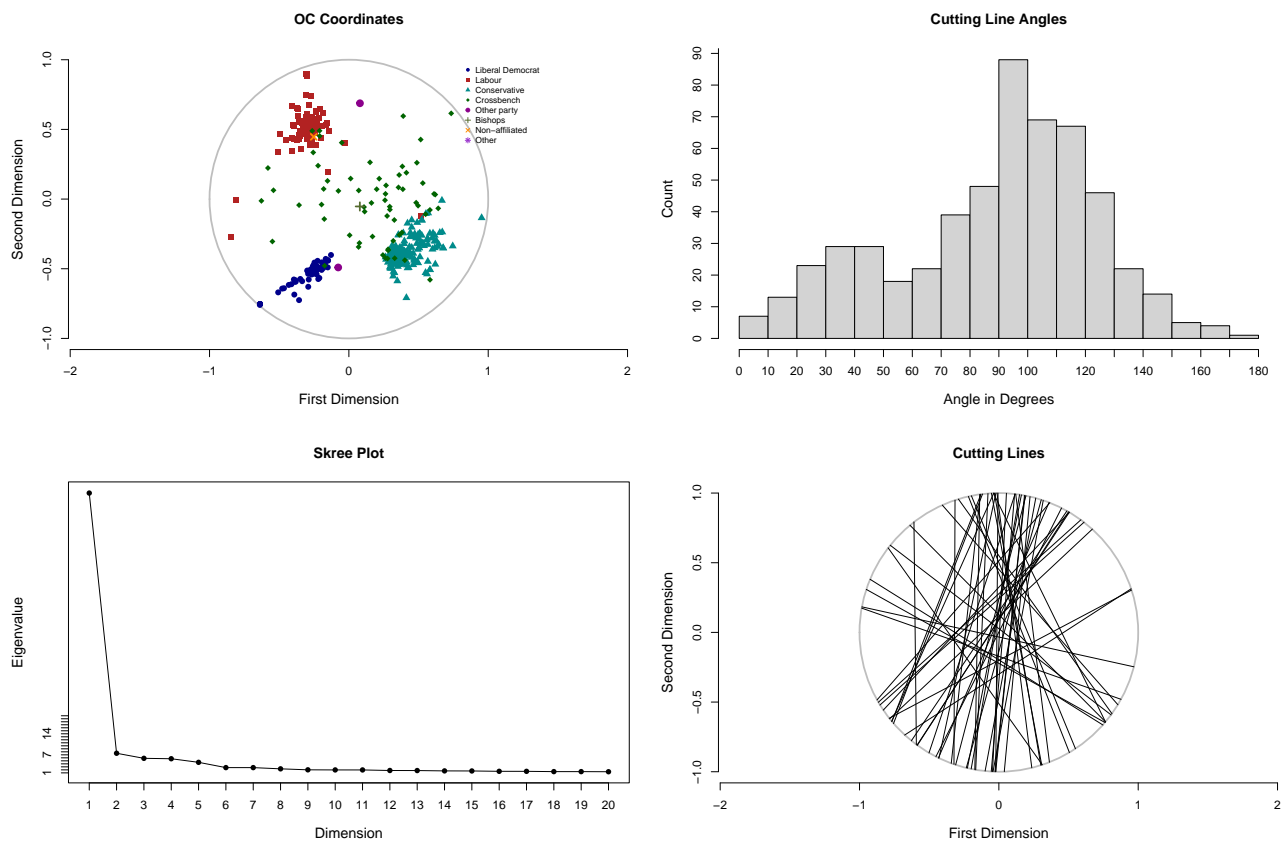

Figure A.1: Optimal Classification estimates, Labour Government (2001-2005). 

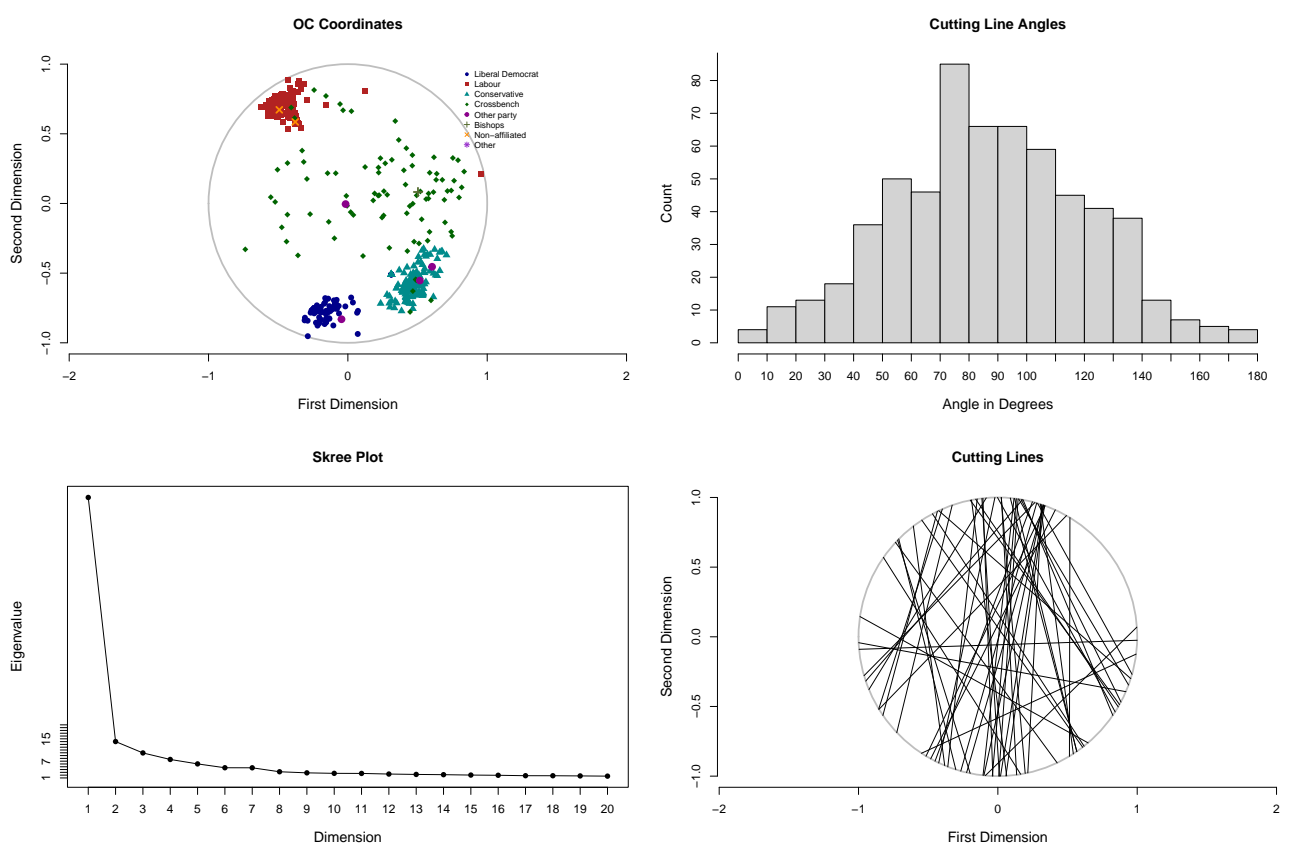

Figure A.2: Labour Government (2005-2010).
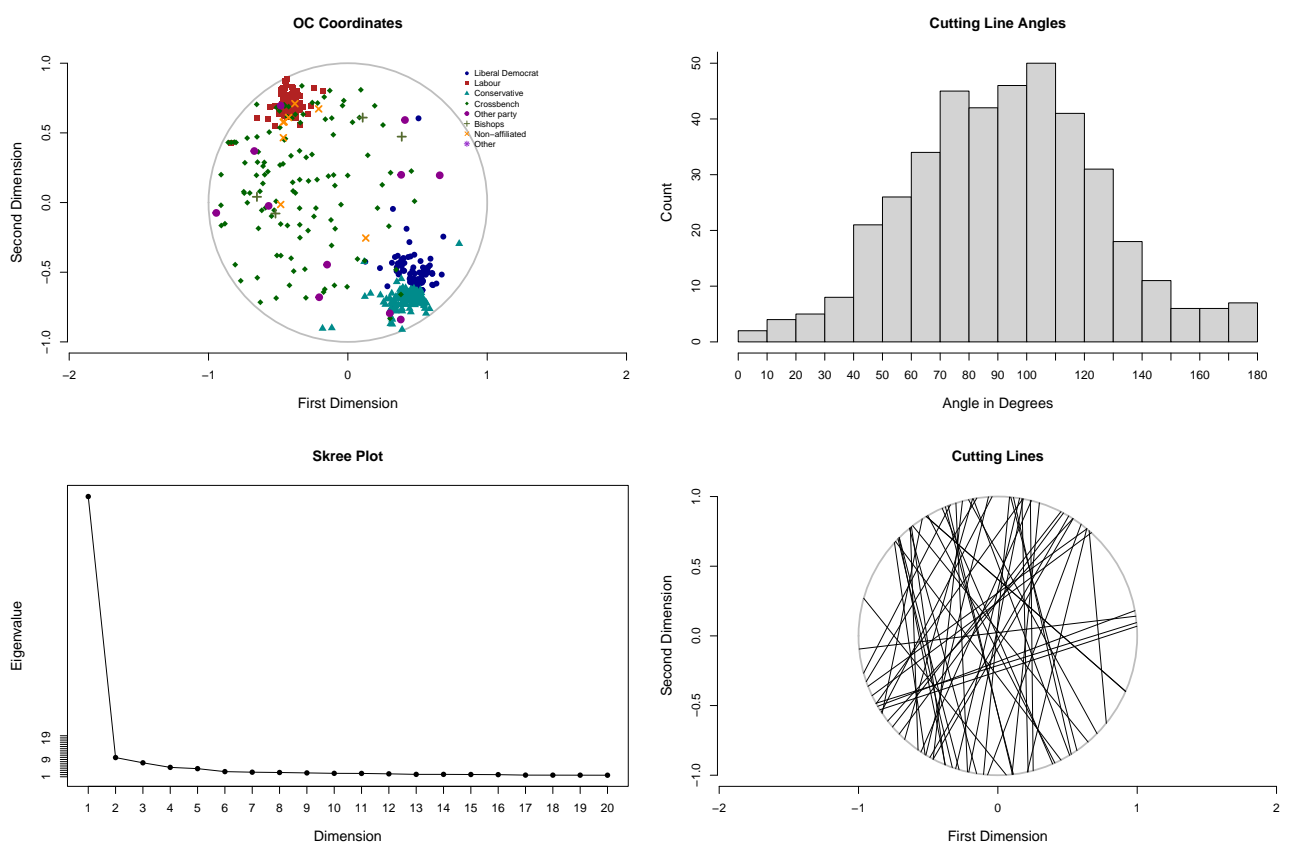

Figure A.3: Conservative/LibDem Government (2010-2015). 

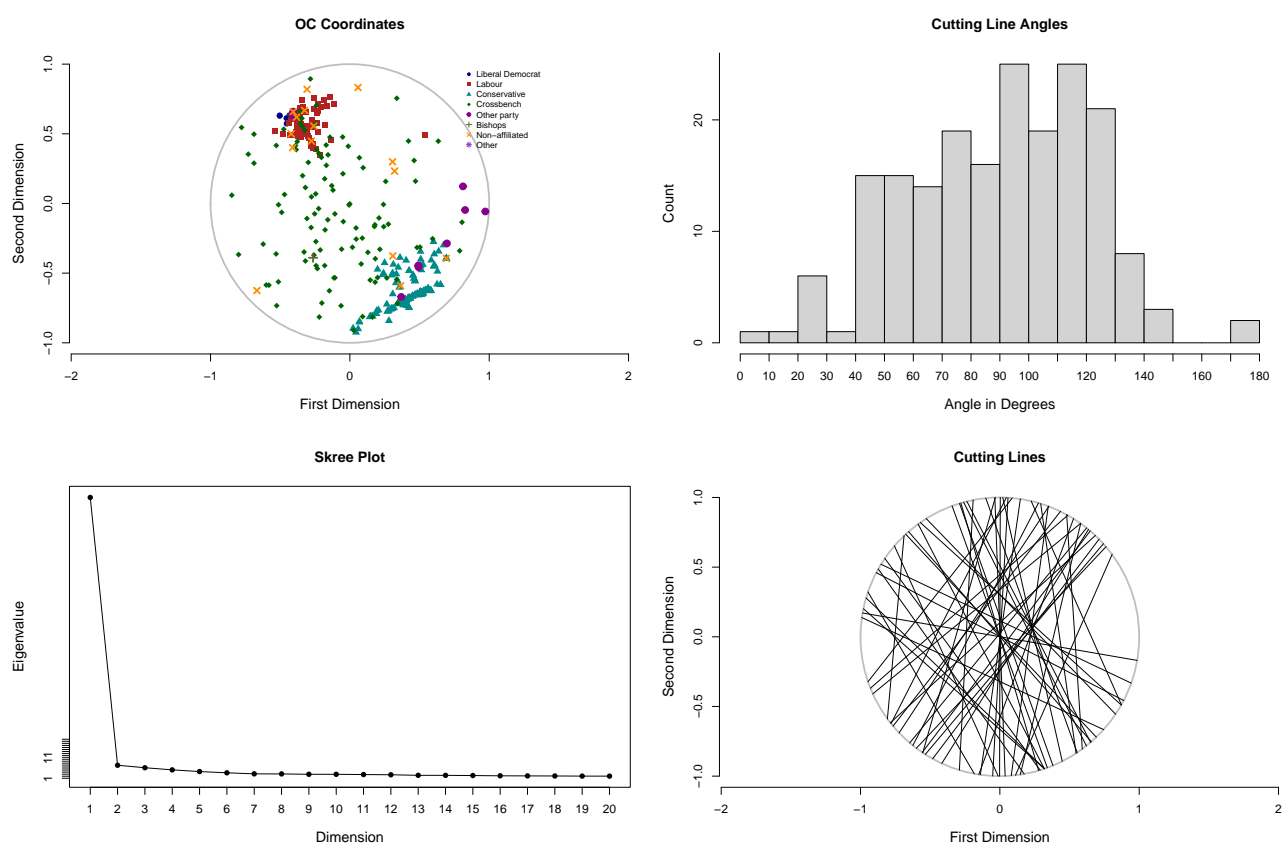

Figure A.4: Conservative Government (2015-2017).
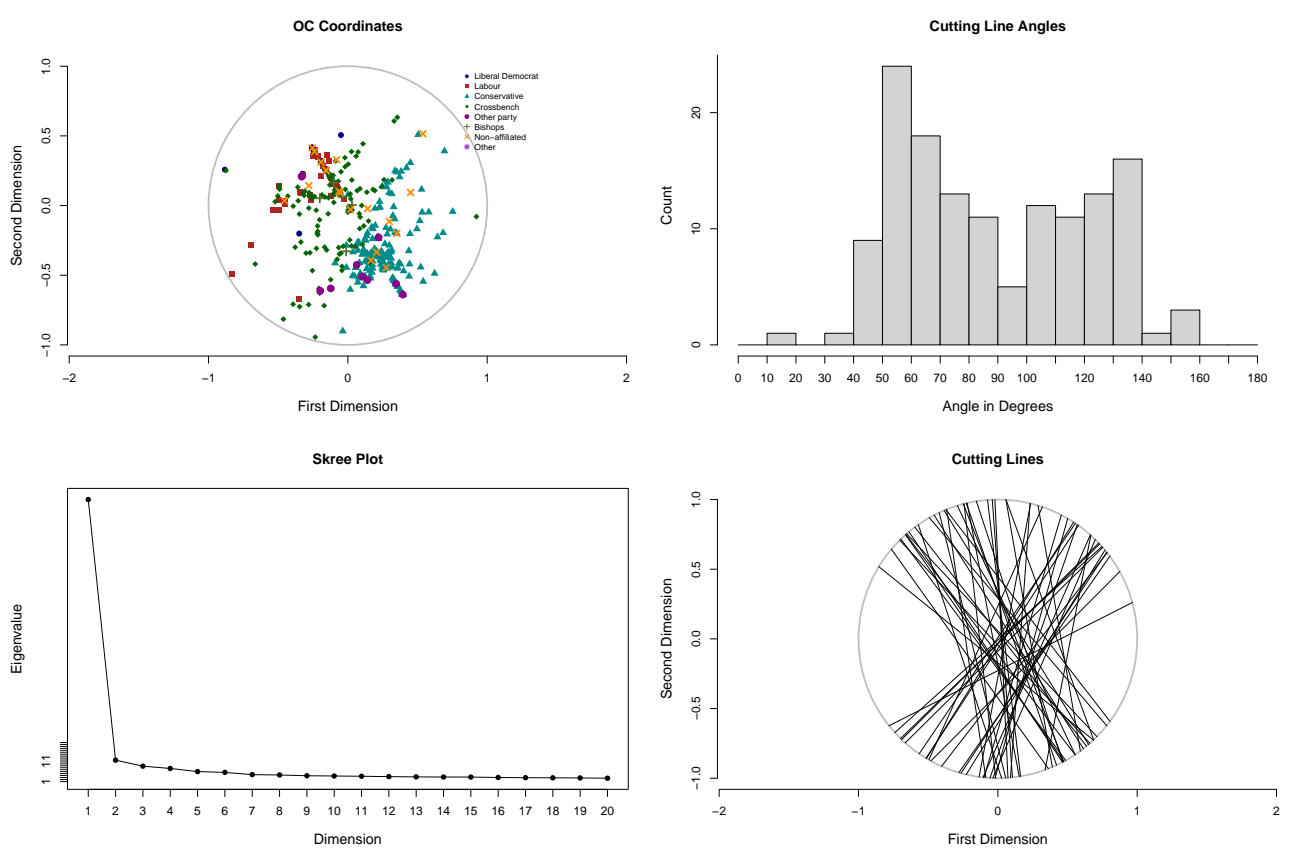

Figure A.5: Conservative Government (2017-2019). 

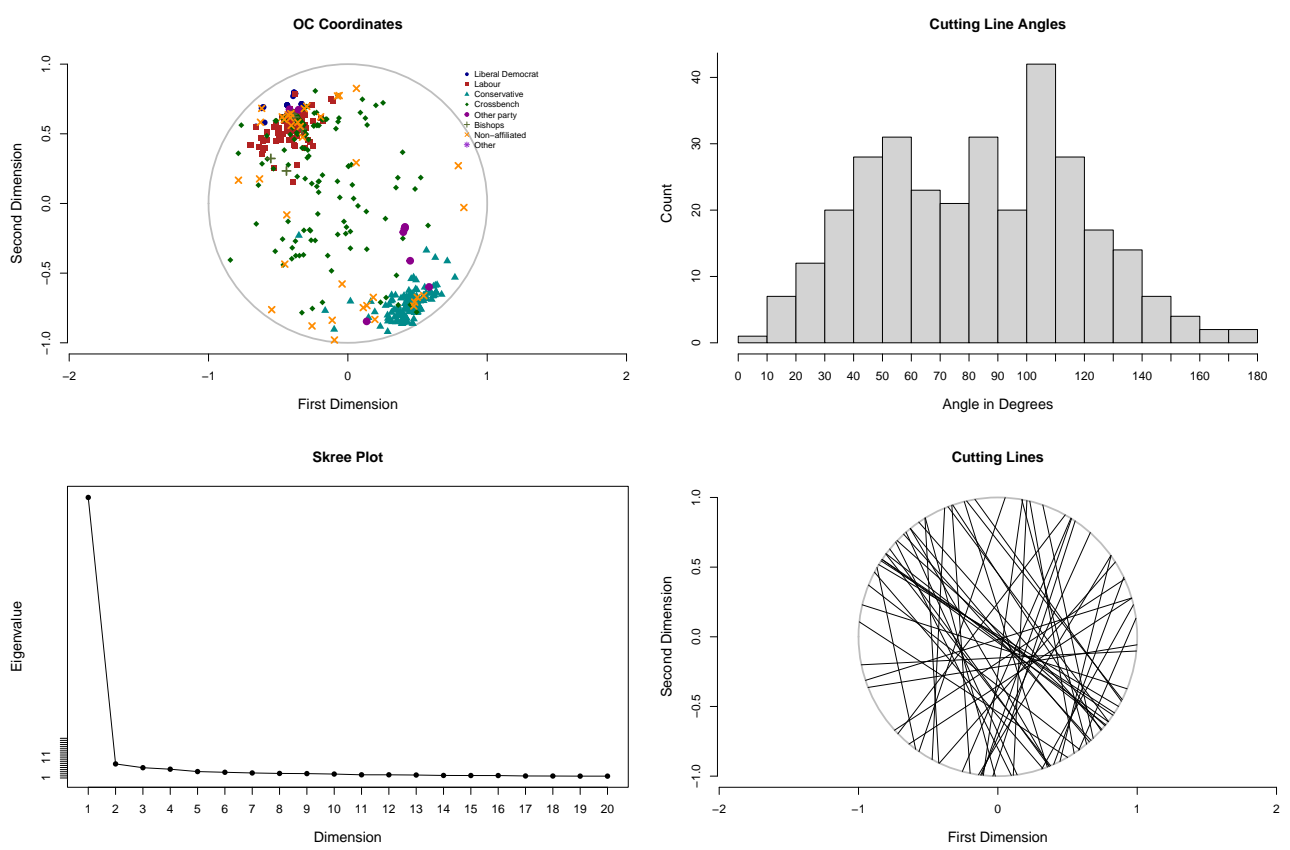

Figure A.6: Conservative Government (2019-2022). 